Research Article

\title{
Performance of Chickpea (Cicer arietinum L.) Genotypes in Sunsari district of Province no. 1 Nepal
}

Govinda Prasad Timsina1, Sujan Karki1, Binod Kumar Gupta1, Rajendra Darai2, Sabita Sharmaz and Shree Prasad Vista4

${ }^{1}$ Jute Research Programm, Itahari, Sunsari, NARC, Nepal

${ }^{2}$ National Grain Legumes Research Program, Khajura, Banke, NARC, Nepal

${ }^{3}$ Directorate of Agricultural Research, Tarahara, Sunsari, NARC, Nepal

${ }^{4}$ National Soil Science Research Centre, NARC, Khumaltar

*Corresponding author e-mail: timsinagp_2005@yahoo.com

(Received: 25/10/2020; Revised: 30/10/2020; Accepted: 05/11/2020)

\begin{abstract}
The present study was carried out to know the performance of growth, yield contributing characters, and reaction against insect pests and disease on chickpea genotypes at Jute Research Program, Itahari, Sunsari, Nepal. A total of twelve chickpea genotypes were sown in Randomized Complete Block Design (RCBD) with three replications and each replicate had 10 lines with an inter and intra row spacing of $40 \mathrm{~cm}$ and $10 \mathrm{~cm}$ respectively. It is of great interest to consider the per se performance of different genotypes on various characters of economic importance, particularly earliness, plant height, nodule number, pod number, seed diameter, 100 seed weight, seed yields, pest and disease incidence. The genotypes ICCV-87312 showed earlier in flowering and maturity while the genotypes KWR-108 and Tara showed the highest and lowest plant height respectively. Likewise, the yield and yield components of overall pooled mean performance of chickpea genotypes ICCV-840508-38 born the maximum pod number, seed diameter, hundred seed weight, and seed yields. With respect to pest incidence, genotype KWR-108 was found to be less susceptible while genotype Tara was found to be more susceptible against pest damage (pod damage). Similarly, the genotypes ICCV-87312 found to be less susceptible while genotypes ICCV-98937 were found to be more susceptible against fusarium wilt disease among the tested genotypes. On the basis of the mean performance of yield components and biotic stress components observed in the present study, the five genotypes viz., ICCV-840508-38, ICCV-98933, KPG-59, ICCV-87312, and KWR-108 were found to be superior genotypes. Therefore, farmers and chickpea producers around study areas and similar agro-ecologies can use those genotypes for chickpea production as well as these materials can be used for the further breeding programs too.
\end{abstract}

Keywords: Chickpea, Genotypes, Yields, Insect pest, Disease etc.

\section{INTRODUCTION}

Legume crops are an essential part of the daily diet for people in many developing countries where a larger proportion of the population cannot afford animal products. Chickpea (Cicer arietinum L.) is an important legume crop widely distributed and cultivated throughout the globe. Chickpea commonly known as Chana in Nepal is an important and unique food riched in carbohydrates, dietary fiber, and protein, and the protein quality is considered to be better than other pulses (Jukanti et al., 2012). It is an important legume to the population, as it is the primary protein source for nearly 2 million Nepalese people (Pande et al., 2005).
Besides being an important source of human and animal food, chickpea also plays an important role in the maintenance of soil fertility, particularly in dry, rain-fed areas (Saxena, 1990 and Katerji et al. 2001). Globally, the chickpea is cultivated on about 11.08 million ha adding 9.77 million tons of grains to the global food baskets with average productivity of $882 \mathrm{~kg}$ ha- 1 . The chickpea is the third most important grain legume in the world after dry beans and dry peas. Its cultivation is mainly confined to Asia with $90 \%$ of the global area and production (Ali and Kumar 2001). In Nepal, it is the second most important pulse crop after lentil and predominantly grown under rain-fed conditions which 
occupy 9653 ha of areas with the production of 10675 Mt (AICC, 2020). Chickpea faces diverse environments for its production in terms of photoperiod, temperature, and precipitation, all of which have a profound effect on growth and development (Khanna-Chopra and Sinha 1987). Chickpea is grown in tropical, subtropical, and temperate regions. It is a valued crop and provides nutritious food for an expanding world population and will become increasingly important in the context of climate change. Chickpea is an important winter legume grown mainly in the rainfed area of Nepal, mainly in rice or maize-based ecosystem either as a sole or mixed crop with other winter crops.

The average productivity of chickpea in Nepal is much lower than the world's average and is also lower as compared to other chickpea-growing countries of Asian regions. There are many factors responsible for low yield, but among those factors use of traditional or low yielding varieties and poor adoption of management practices are considered most important. Nonetheless, chickpea production is being constrained due to several biotic and abiotic stresses worldwide. Among the biotic stresses, fusarium wilt, ascochyta blight, pod borer, cutworm, and abiotic stresses such as drought, heat, soil salinity, low soil fertility, and poor crop management practices are the most important limiting factors in crop production. Improvement in yield and quality of the crop is the primary objective and selection of superior plants is the basis of crop improvement. The efficiency of selection depends on the identification of genetic variability from the phenotypic expression of the characters. Estimation and use of genetic diversity of the available genetic resources are key factors for a successful breeding program (Renganayaki et al., 2001) aimed at improving crop performance under biotic and abiotic stresses. Therefore, this study was incited with the objective to test the performance of chickpea genotypes for their adaptability on growth, yield and yield-related traits, pest, and disease incidence in the study areas.

\section{MATERIALS AND METHODS}

The experiment was conducted at the experimental field of Jute Research Programm, Itahari, Sunsari (at 26015' north latitude and 87o 20' east longitude) during two successive growing periods in 2018 and 2019. A total of twelve chickpea genotypes were sown in Randomized Block Design (RBD) with three replications and each replicate had 10 lines with an inter and Intra row spacing of $40 \mathrm{~cm}$ and $10 \mathrm{~cm}$ respectively. Individual plot size was $4 \mathrm{~m}$ x $2.4 \mathrm{~m}=9.6$ $\mathrm{m} 2$ and $1 \mathrm{~m}$ and $1.5 \mathrm{~m}$ between plot and block respectively. Seeds of chickpea genotypes were collected from the National Grain Legumes Program, Khajura, Banke. The seed was sown in rows on the trail plot and placed at 2-3 cm depth in each row. Two seeds were sown in each hill. The recommended dose of fertilizer was applied at the time of planting. All other agronomic management was applied uniformly in all experiment plots as per the national recommendation for the crop. Observation and data collection was carried out from the experiment fields. Data were collected during the experiment time both from the whole plot, net plot, and sampled plants by random selection from the middle of four rows of each plot. Observations on the following quantitative and qualitative characters were recorded on ten randomly selected plants from each plot in each replication. These plants were tagged before flowering. The data were recorded on Days to emergence, Days to 50\% flowering, Days to maturity, Early plant stand, Final plant stand, Plant height $(\mathrm{cm})$, Branch number, Nodule number, pod number per plant, seed number per pod, seed diameter $(\mathrm{mm}), 100$ seed weight $(\mathrm{gm})$, seed yields (ton/ha), pest and disease incidence (\%). The incidence of pests (pod borer) was recorded at the time of maturity. All the pods of 10 randomly selected plants were plucked and number of healthy and damaged pods were counted and percent pod damage was calculated by using the following formula,

Pod damage $(\%)=\underline{\text { Number of damaged pods }} \quad$ x100 Total number of pods

Similarly, field observations of naturally occurring fusarium wilt incidence were done at 7- day interval at sick plot based on percent of wilt incidence in each plot. Initial recording data for fusarium wilt disease incidence was done when wilting symptoms were visible on the three to five basal leaves of the plants. Disease incidence (DI) on each experimental unit was calculated by using the following formula:

DI $(\%)=$ Number of plants that show wilt symptoms $\times 100$.

Number of both disease infected plants and healthy plants

Analysis of variance (ANOVA) was computed for grain yield and other traits as per the methods described by Gomez and Gomez using Genstat $15^{\text {th }}$ edition computer software for Randomized Complete Block Design.

\section{RESULTS AND DISCUSSION}

\section{Crop phenology}

Statistical analysis of crop phenology data showed the significant $(\mathrm{P} \leq 0.05)$ difference in both the year's aspects days to emergence among the tested twelve chickpea genotypes. The flowering duration of testing genotypes ranges from 82 to 92 and 85 to 96 days while the maturity days range from 126 to 135 and 143 to 153 days respectively during two successive growing seasons. The mean performances for these traits are presented in Table-1. The chickpea genotypes showed early flowering and maturity at first, growing season as 
compared to the second growing season. This might be due to differences in the day length and temperature of the two growing seasons. The pooled mean over a year for flowering and maturity days ranges from 84 to 93 and 138 to 143 days respectively. The earliest $50 \%$ flowering was observed from genotypes ICCV-87312 (84 days), while later flowering was observed from genotypes ICCV-97207 (93 days). Similarly, the early maturing genotypes were observed from genotypes ICCV-87312 and KPG-59 (138 days), while later maturing was observed from the genotypes ICCV98937 and Tara (143 days) among the tested genotypes (Table 1). Similar results for the mean and range for days to $50 \%$ flowering and days to maturity in chickpea genotypes were reported by (Jakhar et. al. 2016) that days to $50 \%$ flowering ranges from 51.67 to 82.67 days and days to maturity ranges from 105 to 123 days. The variation in these characters may be due to the genetic makeup of the genotypes.

Table 1: Mean value of crop phenology related traits of 12 genotypes of chickpea tested at JRP,

Itahari, Sunsari in 2018 and 2019 cropping season.

\begin{tabular}{|c|c|c|c|c|c|c|c|c|c|}
\hline \multirow[b]{2}{*}{ Genotypes } & \multicolumn{3}{|c|}{ Days to emergence } & \multicolumn{3}{|c|}{ Days to $50 \%$ flowering } & \multicolumn{3}{|c|}{ Days to maturity } \\
\hline & 2018 & 2019 & Mean & 2018 & 2019 & Mean & 2018 & 2019 & Mean \\
\hline ICCV-87312 & 9 & 9 & 9 & 82 & 85 & 84 & 132 & 143 & 138 \\
\hline ICCV-98937 & 9 & 9 & 9 & 90 & 89 & 89 & 133 & 153 & 143 \\
\hline ICCV-97207 & 9 & 10 & 9 & 90 & 95 & 93 & 130 & 153 & 142 \\
\hline ICCV-840508-38 & 9 & 10 & 10 & 87 & 92 & 90 & 129 & 150 & 139 \\
\hline ICCV-840508-40 & 9 & 9 & 9 & 86 & 92 & 89 & 128 & 150 & 139 \\
\hline ICCV-840508-41 & 9 & 9 & 9 & 92 & 86 & 89 & 129 & 150 & 140 \\
\hline KWR-108 & 9 & 9 & 9 & 90 & 93 & 92 & 129 & 151 & 140 \\
\hline ICCV-98933 & 9 & 9 & 9 & 88 & 87 & 88 & 126 & 151 & 139 \\
\hline KPG-59 & 92 & 9 & 9 & 87 & 91 & 89 & 129 & 146 & 138 \\
\hline BG-372 & 9 & 9 & 9 & 86 & 92 & 89 & 132 & 151 & 142 \\
\hline ICCV X 840508-31 & 9 & 9 & 9 & 86 & 94 & 90 & 131 & 146 & 139 \\
\hline Tara & 9 & 9 & 9 & 89 & 96 & 92 & 135 & 151 & 143 \\
\hline Grand Mean & 9 & 9 & 9 & 88 & 91 & 89 & 130 & 150 & 140 \\
\hline F - Value & $\mathrm{NS}$ & NS & $\mathrm{NS}$ & $* *$ & $* *$ & $* *$ & $* *$ & $* *$ & $* *$ \\
\hline $\operatorname{LSD}(0.05)$ & C- & - & - & 3.05 & 4.8 & 3.23 & 1.49 & 4.03 & 2.2 \\
\hline C.V $(\%)$ & 7.2 & 6.5 & 5.9 & 2.1 & 3.1 & 2.1 & 0.7 & 1.6 & 0.9 \\
\hline
\end{tabular}

\section{Growth Traits}

Evaluated genotypes showed significant $(\mathrm{P} \leq 0.05)$ differences in plant height and nodule number while it showed non-significant differences on early plant stand, final plant stand, and branch number (Table 2). Mean performances of genotypes for plant height during the 2018 growing season ranges from 38 to 50 whereas, the mean performance of genotypes tested during the 2019 growing season ranges from 36 to 49 respectively. The mean values of chickpea for plant height ranged from 38 to 47 with pooled mean values of 43 . The highest plant height was observed from genotypes KWR-108 $(47 \mathrm{~cm})$ while the lowest plant height was observed from genotypes Tara $(38 \mathrm{~cm})$. Similar results for mean and range for plant height in Chickpea varieties were also reported previously by (Dan et al., 2016, Ejara et. al., 2020 and Ercan et. al., 2013). (Sikdar et.al., 2015) also reported that variation among the varieties in respect of plant height appears due to genotypic variation.

Similarly, the nodule per plant was observed significantly $(\mathrm{P} \leq 0.05)$ differently among the tested genotypes during the two successive growing seasons. Genotypes showed considerable variations in nodule number that ranged from 6 to 13 with the pooled mean performance 9. Six genotypes recorded a superior number of nodules than the mean performance of genotypes (Table 2).

\section{Yield and Yield Components}

The variation of genotypes in pods number per plant, seed diameter, hundred seed weight, and seed yield per hectare showed significantly $(\mathrm{P} \leq 0.05)$ different on tests genotypes while it showed a non-significant difference in seed number per pod (Table 3). The mean performance of pod numbers ranges from 10 to 31,15 to 70 , and 16 to 42 during two consecutive growing seasons and pooled mean respectively. Similarly, the variation in seed diameter ranges from 6.4 to 8.6 and 5.4 to $7.6(\mathrm{~mm})$ during the 2018 and 2019 growing seasons respectively. The pooled mean performance of seed diameter ranges from 5.9 to 8.1 . With respect to a hundred seed weight the range ranges from 17.9 to $27.6,14.7-29.4$, and 16.4 to 28.5 (gm) during 2018, 2019, and overall mean respectively. Likewise, the seed yield of the chickpea genotypes ranges from 0.6 to 2.8 , 1.5 to 6.9 , and 1.2 to 4.4 (ton/ha) respectively during two growing seasons and overall pooled mean. Further, 
the overall pooled mean performance of genotypes showed the highest number of pods (42), seed diameter $(8.1 \mathrm{~mm})$, hundred seed weight $(28.5 \mathrm{gm})$, and seed yields (4.4 ton/ha) from genotypes ICCV-840508-38 (42) while the lowest number of pods (16) from genotypes BG-372, seed diameter $(5.9 \mathrm{~mm})$, hundred seed weight (16.4 gm) from genotypes ICCV-87312, and lowest seed yields (1.2 ton/ha) from genotypes ICCV-840508-41 respectively. The considerable variations in pod number, seed number per plant, and seed per pod were also reported by other authors in
Chickpea (Dan, et al. 2016, Ejara et. al. 2020, Ercan, et al. 2013, and Getachew, et al. 2015). (Sikdar et.al., 2015) reported the variation in the number of pods plant -1 was found due to the variation of branch production and also the genetic variations. (Kabir and Sarkar, 2008) reported that the variation in 100 seed weight of the varieties of chickpea might be due to their different genetic characteristics. (Walia et.al., 2019) reported that yields of different chickpea lines/varieties ranged from 157.5 to $425.4 \mathrm{~kg} \mathrm{ha}-1$.

Table 2: Mean value of growth related traits of 12 genotypes of chickpea tested at JRP, Itahari,

\begin{tabular}{|c|c|c|c|c|c|c|c|c|c|c|c|c|c|c|c|}
\hline \multirow[b]{2}{*}{ Genotypes } & \multicolumn{3}{|c|}{ Early Plant Stand (no.) } & \multicolumn{3}{|c|}{ Final Plant Stand (no.) } & \multicolumn{3}{|c|}{ Plant Height $(\mathrm{cm})$} & \multicolumn{3}{|c|}{ Branch/plant (no.) } & \multicolumn{3}{|c|}{ Nodules/plant (no.) } \\
\hline & 2018 & 2019 & Mean & 2018 & 2019 & Mean & 2018 & 2019 & Mear & 2018 & 2019 & Mean & 2018 & 2019 & Mean \\
\hline ICCV-87312 & 157 & 185 & 171 & 157 & 124 & 140 & 40 & 39 & 39 & 3 & 3 & 3 & 7 & 6 & 6 \\
\hline ICCV-98937 & 138 & 249 & 194 & 135 & 117 & 126 & 46 & 38 & 42 & 3 & 2 & 3 & 6 & 7 & 6 \\
\hline ICCV-97207 & 129 & 147 & 138 & 126 & 99 & 113 & 41 & 49 & 45 & 2 & 3 & 3 & 13 & 13 & 13 \\
\hline ICCV-840508-38 & 144 & 147 & 145 & 142 & 79 & 111 & 43 & 46 & 44 & 3 & 3 & 3 & 10 & 11 & 11 \\
\hline ICCV-840508-40 & 152 & 190 & 171 & 149 & 109 & 129 & 45 & 42 & 43 & 3 & 3 & 3 & 7 & 7 & 7 \\
\hline ICCV-840508-41 & 130 & 137 & 134 & 126 & 64 & 95 & 39 & 41 & 40 & 3 & 3 & 3 & 10 & 9 & 10 \\
\hline KWR-108 & 142 & 163 & 153 & 142 & 103 & 123 & 50 & 44 & 47 & 3 & 3 & 3 & 9 & 9 & 9 \\
\hline ICCV-98933 & 131 & 156 & 143 & 131 & 88 & 109 & 45 & 48 & 46 & 3 & 3 & 3 & 8 & 7 & 8 \\
\hline KPG-59 & 146 & 141 & 143 & 146 & 53 & 100 & 41 & 49 & 45 & 3 & 2 & 3 & 13 & 12 & 12 \\
\hline BG-372 & 123 & 165 & 144 & 123 & 79 & 101 & 47 & 36 & 42 & 2 & 3 & 3 & 7 & 6 & 6 \\
\hline ICC X 840508-31 & 133 & 151 & 142 & 132 & 74 & 103 & 44 & 42 & 43 & 3 & 3 & 3 & 10 & 11 & 10 \\
\hline Tara & 125 & 167 & 146 & 125 & 92 & 108 & 38 & 38 & 38 & 3 & 3 & 3 & 10 & 10 & 10 \\
\hline Grand Mean & 138 & 167 & 152 & 136 & 90 & 113 & 43 & 43 & 43 & 3 & 3 & 3 & 9 & 9 & 9 \\
\hline F-value & NS & NS & NS & NS & NS & $*$ & ** & $* *$ & $* *$ & NS & NS & NS & $* *$ & $* *$ & $* *$ \\
\hline $\operatorname{LSD}(0.05)$ & - & & - & - & - & 26.42 & 3.86 & 7.12 & 4.27 & - & - & -10 & 2.95 & 3.03 & 2.93 \\
\hline C.V(\%) & 15.4 & 24 & 14.2 & 15.6 & 30.6 & 13.8 & 5.3 & 9.9 & 5.9 & 14.9 & 15.6 & 14.6 & 19 & 20.1 & 19.1 \\
\hline
\end{tabular}

*, Significant at $\mathrm{P} \leq 0.05$. **, $\mathrm{P} \leq 0.01$. LSD, least significant difference. $\mathrm{CV}$, coefficient of variance,

Table 3: Mean value of yield and yield components traits of 12 genotypes of chickpea tested at JRP, Itahari, Sunsari in 2018 and 2019 cropping season.

\begin{tabular}{|c|c|c|c|c|c|c|c|c|c|c|c|c|c|c|c|}
\hline \multirow[b]{2}{*}{ Genotypes } & \multicolumn{3}{|c|}{ No. of pod/plant } & \multicolumn{3}{|c|}{ No. of Seed/pod } & \multicolumn{3}{|c|}{ Seed diameter $(\mathrm{mm})$} & \multicolumn{3}{|c|}{100 seed Wt. $(\mathrm{gm})$} & \multicolumn{3}{|c|}{ Seed Yields (ton/ha) } \\
\hline & 2018 & 2019 & Mean & 2018 & 2019 & Mean & 2018 & 2019 & Mean & 2018 & 2019 & Mean & 2018 & 2019 & Mean \\
\hline ICCV-87312 & 31 & 47 & 39 & 1 & 1 & 1 & 6.4 & 5.4 & 5.9 & 18.2 & 14.7 & 16.4 & 2.1 & 2.8 & 2.5 \\
\hline ICCV-98937 & 18 & 46 & 32 & 1 & 2 & 1 & 7.2 & 6.1 & 6.7 & 17.9 & 21.7 & 19.8 & 1.2 & 3.2 & 2.2 \\
\hline ICCV-97207 & 10 & 31 & 20 & 2 & 1 & 1 & 8.4 & 7.3 & 7.9 & 19.7 & 21 & 20.3 & 1.1 & 4.7 & 2.9 \\
\hline ICCV-840508-38 & 15 & 70 & 42 & 1 & 1 & 1 & 8.6 & 7.6 & 8.1 & 27.6 & 29.4 & 28.5 & 2.8 & 5.9 & 4.4 \\
\hline ICCV-840508-40 & 11 & 43 & 27 & 1 & 1 & 1 & 8.0 & 6.9 & 7.4 & 19.7 & 22.7 & 21.2 & 2.1 & 2.8 & 2.5 \\
\hline ICCV-840508-41 & 17 & 18 & 18 & 1 & 1 & 1 & 6.5 & 5.5 & 6.0 & 20.7 & 25.3 & 23.0 & 0.8 & 1.5 & 1.2 \\
\hline KWR-108 & 22 & 41 & 31 & 2 & 1 & 1 & 7.1 & 6.1 & 6.6 & 19.7 & 22.0 & 20.9 & 1.7 & 3.0 & 2.3 \\
\hline ICCV-98933 & 16 & 49 & 32 & 1 & 1 & 1 & 7.8 & 6.8 & 7.3 & 17.3 & 23.0 & 20.1 & 1.4 & 6.9 & 4.2 \\
\hline KPG-59 & 17 & 65 & 41 & 1 & 2 & 1 & 7.1 & 6.1 & 6.6 & 18.9 & 25.0 & 21.9 & 1.8 & 6.3 & 4.0 \\
\hline BG-372 & 17 & 15 & 16 & 1 & 1 & 1 & 7.1 & 6.1 & 6.6 & 20.6 & 24.3 & 22.5 & 1.0 & 1.9 & 1.4 \\
\hline ICC X 840508-31 & 21 & 21 & 21 & 2 & 1 & 1 & 7.7 & 6.7 & 7.2 & 20.7 & 21.7 & 21.2 & 1.2 & 2.2 & 1.7 \\
\hline Tara & 15 & 61 & 38 & 2 & 1 & 1 & 7.1 & 6.1 & 6.6 & 19.7 & 22.3 & 21.0 & 0.6 & 2.8 & 1.7 \\
\hline Grand Mean & 17.4 & 42.3 & 29.8 & 1.4 & 1.3 & 1.3 & 7.4 & 6.4 & 6.9 & 20.0 & 22.8 & 21.4 & 1.5 & 3.7 & 2.6 \\
\hline F-value & $* *$ & $* *$ & $* *$ & NS & NS & NS & $*$ & $*$ & $*$ & $* *$ & $* *$ & $* *$ & $* *$ & $* *$ & $* *$ \\
\hline LSD (0.05) & 2.5 & 16.1 & 8.5 & - & - & - & 1.3 & 1.3 & 1.3 & 3.6 & 3.4 & 2.2 & 1.2 & 1.0 & 0.9 \\
\hline C.V $(\%)$ & 8.3 & 22.5 & 16.7 & 16.8 & 21.9 & 14.5 & 10.2 & 11.9 & 11.0 & 10.5 & 8.9 & 6.1 & 20.4 & 16.0 & 21.3 \\
\hline
\end{tabular}

*, Significant at $\mathrm{P} \leq 0.05 . * *, \mathrm{P} \leq 0.01$. LSD, least significant difference. $\mathrm{CV}$, coefficient of variance, 


\section{Biotic stress component}

Insect pests and diseases are the major biotic stress factors of chickpea production. Analysis of variance on biotic stress components showed significant $(\mathrm{P} \leq 0.05)$ differences on test genotypes. Insect pest mainly chickpea pod borer [Helicoverpa armigera Hubner) Lepidoptera, Noctuidae] is the main devastating pest of the crops. Pod damage (\%) by pod borer was significantly different among the test genotypes (Table 4). The overall mean performance of the two consecutive growing seasons showed that the maximum amount of pest incidence (pod damage) was recorded from genotypes Tara $(50.3 \%)$ followed by genotypes ICCV-840508-40 (49.4\%) and BG-372 (48.2\%) respectively and considered as more susceptible genotypes against chickpea pod borer. Similarly, the pest incidence was minimum in genotypes KWR-108 (15.3\%) followed by genotypes ICCV-98933 (26.1\%) and ICCV-87312 (26.3\%) respectively, and considered comparatively less susceptible genotypes against chickpea pod borer. The results of pod damage percentage are in agreement with the results of the authors who stated similar findings, i.e., varieties with more pod borer infestation had more percentage damaged pods and vice versa (Sarwar et al., 2011). (Nadeem et al., 2011) studied ten advanced chickpea genotypes against pod borer and reported that pod damage ranged from 8.2 to $15.8 \%$. (Hossain, 2009) recorded pod damage range from 2.80 to 13.47 /plant in 20 different chickpea genotypes and found that the genotype with maximum pod damage was most susceptible. (Parkash et al. 2007) reported 60.1- 94 and $70-95 \%$ pod damage by chickpea pod borer respectively. The much variation in pod damage may be due to differences in regional climatic conditions and the tested genotypes.

Fusarium wilt is a major disease of chickpea which causes economic damages to the crops. The overall pooled mean performance of the disease incidence on chickpea ranges from 14.3 to $26.9 \%$ with the mean value of $20.5 \%$ respectively (Table 4 ). The maximum amount of disease incidence was recorded from genotypes ICCV-98937 (26.9\%), followed by genotypes KPG-59 (24.8\%) and BG-372 (24\%) respectively, and considered as more susceptible genotypes against the wilt and blight diseases. Likewise, the minimum amount of disease incidence was recorded from genotypes ICCV-87312 (14.3\%), followed by genotypes ICCV-97207 (15.3\%) and KWR-108 (15.7\%) respectively, and considered as less susceptible genotypes against wilt and blight diseases. Diseases, such as Fusarium wilt and Ascochyta blight have affected the crop throughout the growing season and at the pod set, respectively. (Anjaneya Reddy,
2002) suggested that complete wilting, plants exhibited turgidity losses and yellowing of leaves in a plant infected with wilt disease. (Ahmad et al., 2010) indicated that some of the cultivar showed resistance reaction at the seedling stage while others showed susceptible reaction at the physiological maturity stage. (Iqbal et al., 2010) were identified five genotypes with genes for tolerance against wilt disease which could be further utilized for developing high yield cultivars with dual tolerance.

Table 4: Mean value of biotic stress component traits of 12 genotypes of chickpea tested at JRP, Itahari, Sunsari in 2018 and 2019 cropping season.

\begin{tabular}{lllllll}
\hline & \multicolumn{3}{c}{ Pest Incidence $(\%)$} & \multicolumn{3}{c}{ Disease Incidence (\%) } \\
\cline { 2 - 7 } Genotypes & 2018 & 2019 & Mean & 2018 & 2019 & Mean \\
\hline ICCV-87312 & 41.2 & 11.3 & 26.3 & 11.6 & 16.6 & 14.3 \\
ICCV-98937 & 74.6 & 13.6 & 44.1 & 26.4 & 27.7 & 26.9 \\
ICCV-97207 & 64.7 & 4.3 & 34.5 & 12.6 & 18.8 & 15.3 \\
ICCV-840508-38 & 54.1 & 4.8 & 29.5 & 15.8 & 24.8 & 19.1 \\
ICCV-840508-40 & 64.6 & 34.2 & 49.4 & 17.3 & 23.1 & 19.9 \\
ICCV-840508-41 & 36.6 & 20.2 & 28.4 & 18.5 & 28.8 & 23.6 \\
KWR-108 & 23.1 & 7.4 & 15.3 & 13.7 & 18.5 & 15.7 \\
ICCV-98933 & 33.6 & 18.6 & 26.1 & 15.8 & 22.1 & 19.0 \\
KPG-59 & 66.7 & 15.1 & 40.9 & 18.1 & 32.7 & 24.8 \\
BG-372 & 70.1 & 26.4 & 48.2 & 21.1 & 26.3 & 24.0 \\
ICC X 840508-31 & 40.6 & 35.6 & 38.1 & 17.8 & 26.6 & 22.3 \\
Tara & 70.3 & 30.4 & 50.3 & 18.1 & 22.7 & 20.6 \\
\hline Mean & 53.35 & 18.49 & 35.9 & 17.2 & 24.0 & 20.5 \\
F-value & $* *$ & $* *$ & $* *$ & $*$ & $*$ & $* *$ \\
LSD $(0.05)$ & 16.08 & 12.33 & 9.58 & 5.54 & 7.90 & 4.05 \\
C.V $(\%)$ & 16.6 & 49.4 & 15.7 & 19.0 & 19.6 & 11.7 \\
\hline
\end{tabular}

*, Significant at $\mathrm{P} \leq 0.05 .{ }^{* *}, \mathrm{P} \leq 0.01$. LSD, least significant difference. $\mathrm{CV}$, coefficient of variance,

\section{CONCLUSION}

The results of this investigation showed significant variation among the genotypes in growth, yields, pest, and disease incidence traits among the genotypes studied. On the basis of the mean performance of yield components and biotic stress components observed in the present study the five genotypes viz., ICCV840508-38, ICCV-98933, KPG-59, ICCV-87312, and KWR-108 were found to be superior genotypes. Therefore, farmers and chickpea producers around study areas and similar agro-ecologies can use those genotypes for chickpea production as well as these genotypes can be used for further breeding programs too.

\section{Acknowledgment}

The authors are thankful for the Jute Research Program, Itahari, Sunsari as well as National Grain Legumes Research Program, Khajura, Banke Nepal for providing research supports. Thanks are also due to the Nepal Agricultural Research Council (NARC) for providing the necessary budget and facilities to carry out the study. 


\section{REFERENCES}

Ahmad, S., Beniwal, S.P.S. and Tadesse, N. 2010. Field screening of chickpea for resistance to wilt/root rots in Ethiopia. International Chickpea Newsletter 22: 3436.

AICC (2020) Krishi Dairy, Agriculture Information and Communication Center (AICC) MoALD, Hariharbhawan, Nepal.

Ali, M., \& Kumar, S. 2001. An overview of chickpea research in India. Indian Journal of Pulses Research, 14(2): 8189.

Anjaneya, R. B. 2002. Variability of Fusarium udum and evaluation of Pigeonpea (Cajanus cajana (L.) Mills) genotypes.M.Sc. Thesis,Univ.Agric. Sci., Bangalore, $115 \mathrm{pp}$.

Dan, S. J., Kamble, M. S., Abhishek, S., and Saket, K., 2016. "Performance of chickpea (Cicer arietinum 1.) genotypes in kolhapur region." International Journal of Agriculture, Environment and Biotechnology, 9: 283-289.

Ejara, E., Kitaba, K., Misganaa, Z., \& Tesama, G. 2020. Performance Evaluation of Chickpea Varieties (Cicer arietinum L.) at Bule Hora and Abaya Southern Ethiopia. Journal of Biotechnology Research, 6(5): 34-40.

Ercan, C., Ali, K., and Hasan, D., 2013. "Determination of some agricultural characters of chickpea (Cicer arietinum 1.) genotypes. World academy of science, engineering and technology." International Journal of Agricultural and Biosystems Engineering, 7: 10921095.

Getachew, T., Firew, M., Asnake, F., and Million, E., 2015. "Genotype $\mathrm{x}$ environment interaction and stability analysis for yield and yield related traits of Kabulitype Chickpea (Cicer arietinum L.) in Ethiopia." African Journal of Biotechnology, 14: 1564-1575.

Gomez, K. A. and A. A. Gomez.1984. Statistical Procedures for Agricultural Research.704PP.

Hossain MA, 2009. Field screening of chickpea genotypes against pod borer. Bangladesh Journal of Agricultural Research, 34(3): 517-521.

Iqbal,M.A., Iqbal, S.M.,Ayub, N.,Ahmad, Y.,andAkram, A. 2010. Identification of resistant sources in chickpea against Fusarium wilt. Pak. J. Bot 42(1): 417- 426.

Jakhar, D. S., Kamble, M. S., Singh, A., \& Kumar, S. 2016. Performance of Chickpea (Cicer arietinum L.) Genotypes in Kolhapur Region. International Journal of Agriculture, Environment and Biotechnology, 9(2): 283-289.

JRP 2018. Annual Report on Jute Research Program (JRP) Itahari, Sunsari, Nepal Agricultural Research Council.

JRP 2019. Annual Report on Jute Research Program (JRP) itahari, Sunsari, Nepal Agricultural Research Council.

Jukanti AK, Gaur PM, Gowdal CLL and Chibbar RN, 2012. Nutritional quality and health benefits of chickpea (Cicer arietinum L.): A review. British Journal of Nutrient, 108(1): 11-26.
Kabir, M.H., M.A.R. Sarkar, M. Begum and M.A. Salam. 2008. Yield performance of chickpea as affected by planting date, variety and plant density. J. Agron., 3(1): 18-24.

Katerji N., Van Hoorn J.W., Hamdy A., Mastrorilli M., Owies T., Malhotra R.S. 2001. Response to soil salinity of chickpea varieties differing in drought tolerance. Agr. Water Manag., 50: 83-96.

Nadeem S, Hamed M, Shafique M, Atta BM and Shah TM, 2011. Evaluation for resistance in kabuli chickpea genotypes against chickpea pod borer, Helicoverpa armigera (Hubner) (Lepidoptera: Noctuidae) under field conditions. Songklanakarin Journal of Science and Technology, 33(3): 291-294.

NGLRP 2018. Annual Report on National Grain Legumes Research Program (NGLRP) Khajura, Banke, Nepal Agricultural Research Council.

Pande, S., Stevenson, P., Rao, J. Narayana, Neupane, R. K., Chaudhary, R. N., Grzywacz, D., Bourai, V. A. \& Kishore, G. Krishna. 2005. "Reviving Chickpea Production in Nepal Through Integrated Crop Management, with Emphasis on Botrytis Gray Mold". Plant Disease, 89: 1252-1262.

Parkash, M.R., U. Ram and A. Tariq. 2007. Evaluation of chickpea (Cicer arietinum L.) germplasms for the resistance to gram pod borer, Helicoverpa armigera Hubner (Lepidoptera: Noctuidae). J. Entomol. Res. 31: 215-218.

Prasai, H. K. 2019. Performance evaluation of lentil and chickpea genotypes in Doti district of Nepal. International Journal of Applied Biology, 3(2), 46-56.

Renganayaki, K., J.C. Read and A.K. Fritz, 2001. Genetic diversity among Texas bluegrass (Poa arachnifera torr.) revealed by AFLP and RAPD markers. Theor. Appl. Genet., 102: 1037-1045.

Sarwar, M., Ahmad, N. and Tofique, M. 2011. Identification of susceptible and tolerant gram (Cicer arietinum L.) genotypes against gram pod borer (Helicoverpa armigera) (Hubner). Pak. J. Bot. 43: 1265-1270.

Saxena N.P. 1990. Status of chickpea in the Mediterranean basin. In: Present Status and Future Prospects of Chickpea Crop Production and Improvement in the Mediterranean Countries. Options Méditerraneennes (CIHEAM) Ser. A, 9: 17-24.

Sikdar, S., Abuyusuf, M., Ahmed, S., \& Tazmin, M. F. 2015. Variety and Sowing Time on the Growth and yield of Chickpea (Cicerarietinum L.) in Souther Region of Bangladesh.

Walia MK, Mohammed YA, Franck WL, Chen C. 2019. Evaluation of early seedling development of Chickpea and its relation to seed yield. Agrosyst Geosci Environ. 2020;3:e20005. 